\title{
The Airline Service Quality Affecting Post Purchase Behavioral Intention: Empirical Evidence from the Low Cost Airline Industry
}

\author{
Weerawit Lerrthaitrakul and Vinai Panjakajornsak, Member, IEDRC
}

\begin{abstract}
The main purpose of this study is to examine the relationship between five dimensions of service quality of low cost airlines and consumers' post purchase behavioral intentions. This study found that in low cost carriers, three service quality factors comprisingassurance, reliability and empathyhave a significant influence on consumers' post purchase behavioral intentions.
\end{abstract}

Index Terms-About Airline service quality, post purchase, behavioral intention, low cost carriers

\section{INTRODUCTION}

According to a prediction by the International Air Transport Association [1], the air transportation industry will boom significantly in the current climate. An increase in the average number of people travelling by air will be 5.3 percent between 2012 and 2016. It has also been predicted that the number of passengers will increase by around 28.5 percent in 2016.

The low cost airlines will have the potential to grow explosively and play a significant role in world air transportation. In fact, low cost airlines have been a great choice of travelling since 1970. O'Connell and Williams [2] explained that the business success of low cost airlines was started in 1970 when Southwest Airline was the first airline that launched this type of operation. Since then, the low cost airlines have become choices for people in many areas to travel with. In 2000, it came to ASIA.

In Thailand, the low cost airline business had a chance to operate in Thailand and has successfully grown due to support from the Thai government. The government viewed that while there were a lot of road works to complete, people should have other choices to travel. Saha and Theingi [3] mentioned that the three main low cost airlines doing their business in Thailand were Nok Air, Orient Thailand Thai Air Asia.

From previous studies, it has been found that due to an increased number of low cost airlines, consumers have more choices and they can choose to travel with an airline giving them their best quality service. To continuously grow and gain competitive advantage over other low cost airlines, each low cost airline company needed to promote themselves and ensure that their passengers could receive an

Manuscript received August 11, 2013; revised October 25, 2013.

Weerawit Lertthaitrakul and Vinai Panjakajornsak are with Administration and Management College, King Mongkut's Institute of Technology Ladkrabang, Bangkok, CO 24130 Thailand (e-mail: khunweerawit@gmail.com, vinaidba6@gmail.com). impressive service quality [4]. It is also interesting to find in a study by Kim and Lee [5] that the low price of air fares in low cost airlines might no longer be the most significant factor for passengers to choose which airline to fly with, but perceptions about service quality of low cost airlines, was. The satisfactory quality of service refers to how the service could response to the needs of passengers. Moreover, it found that the past perception of passengers about satisfactory service quality could significantly influence their decision when choosing the same airline again [6], [7]. Also, it is therefore, interesting to examine whether or not the experiences about service quality of low cost airlines shared by experienced passengers would become one of the important marketing strategies used by a low cost airline today.

The main purpose of this study was therefore to examine the relationship between five dimensions of service quality of low cost airlines and consumers' post purchase behavioral intentions. The findings of this study will help guide the low cost airline companies to properly develop their service quality which will, in time, help to generate better profits for the companies.

\section{THEORETICAL BACKGROUND AND HYPOTHESES}

\section{A. Airline Service Quality}

Chou, Liu, Huang, Yih, and Han [8] viewed that the service quality of airlines became a key success factor for airline companies nowadays. They competed with each other by increasing their service quality to satisfy their passengers. Gilbert and Wong (9) agreed with this claiming that the service quality of airlines had a direct influence on their company's profits. Delivering impressive service to their passengers allowed the companies to survive in this highly competitive sector as impressed customers were likely to come back, companies would get a lot of market share and eventually earn high profits [6].

In many low cost airlines, the concept of improving high quality service had recently been considered as a profound company strategy. The quality of service that could increase passengers' satisfaction levels had become a must do strategy which is more important than just promoting cheap airfares [10].

Parasuraman, Zeithaml, and Berry [11] explained that SERVQUAL model had been widely used as a tool to measure the service quality of airlines. Pakdil \& Aydın [12] SERVQUAL was found as a tool to measure service quality in many past studies [6], [8], [9], [11] also adopted SERVQUAL to measure service quality of airlines in their 
studies. Five dimensions of service quality that can be adapted to measure service quality in the airline business were comprised of 1) Tangible; 2) Reliability; 3) Responsiveness; 4) Assurance; 5) Empathy. Tangible dimension refers to visible and touchable things or equipment provided for passengers' comfort on board. This might include size of passenger seats, area in which passengers could comfortably stretch their legs, catering such as food, quality of food, as well as on board entertainment services such as magazines, newspapers and games.

Reliability could be explained by the number of effective services given to passengers. Their services must all the time be done properly and on time. This dimension for example can often be the criteria to measure how an airline could properly facilitate their customers, such as at the time their customers try to check in or buy a ticket.

Responsiveness dimension referred to how airline staff sincerely showed their willingness and readiness to help solve customers' problems For example, how the staff could help them cancel their flight, deliver their stuff on time, help or respond to their losing luggage or promptly help customers in any emergency cases.

Assurance dimension referred to how the airline could make their customers trust them and feel confident to travel with the airline in terms of their traveling security.

Empathy dimension could be shown when the airline displayed their tenderness and care to each passenger. Services such as leading passenger to their seats, introducing dishes passengers are having or online booking and frequent flyer schemes are examples of areas measured in this criteria [5], [6], [13], [14].

\section{1) Post purchase behavioral intentions}

Huang [14] highlighted that perceptions about service quality was one of the key sucess factors influencing what customers might do after experiencing services. What they perceived in the past could come to their mind and help them when considering whether they should repurchase another air ticket for their next trip with the same airline. It was found that passengers shared both their impressed and not impressed experiences about the service quality they received by word-of-mouth. All of these could be called behavioral intentions. This agreed with studies conducted by Park et al. [6] and Yang et al. [7]. Both of them found that quality of services had a direct influence on customers' behavioral intentions. The customers themselves might come back and use the same service with the same company again or they may share their experiences regarding how they were satisfied by service quality and the image of the airline, with other people. Hutchinson, Lai, and Wang [15] and Pakdil and Aydin [12] confirmed this presenting that people consulted their own experiences before making their next purchasing decision. It went without saying that a little gap in service quality could turn down customers' satisfaction, as customers tend to think about their past experiences or consult experienced customers before making their purchasing decision making. Consumers' behavior during their post-purchasing period can be viewed in two ways which were Re-purchasing, and sharing their experience to others through word-of-mouth channel.
From the above review of literature, the researcher set up the following hypothesis: There is a significant relationship between the five dimensions of service quality on customers' post purchase behavioral intentions.

\section{RESEARCH METHODS}

\section{A. Research Sample and Data Collection}

Sampling in this study were 425 experienced passengers flying with one of three low cost airlines in Thailand namely 1) Nok Air, 2) Thai Air Asia, and 3) Orient Thai)and who had searched only to get some information before deciding to travel.An online questionnaire was used as a data collection instrument in this study. The data was collected between June and August 2013. The link of the online questionnaire was posted on airlines' Facebook (www.facebook.com/AirAsiaThailand;

www.facebook.com/nokairlines; www.facebook.com/FlyOrientThai) and Thai popular review websites (www.pantip.com/forum/blueplanet).

\section{B. Instrument}

A twenty two item seven-Likert-type online questionnaire used in this study was adapted based on the popular one found in previous studies and Cronbrach's coefficient was used to measure internal consistency and reliability. Only questions which received over 0.7 were included in the questionnaire [3], [16], [17]. The test had a twenty two items and a simply asked participant to make a tick in response to the choice that best describes their opinion. The choices ranged from strongly disagree to strongly agree.

\section{RESUlTS AND DisCUSSION}

\section{A. Demographics}

The majority of the participants in this study were male $(59.1 \%)$. their ages were between $31-35$ years $(45.9 \%)$ and their educational level was bachelor degree graduates (48.5\%), their income was15,001-25,000Baht (28.5\%), they were working in a private company $(50.1 \%)$ and travelling was their travelling purpose $(69.2 \%)$ (See Table I).

\section{B. Reliability}

Cronbach's alpha is the most commonly accepted formula for assessing the reliability of measurement scales with multi point items. All scales were proven sufficient reliability as they exceeded regarding the reliability recommended value of 0.7 or higher [18]. The analysis from this study showed that the overall alpha was 0.93 . Therefore, the questionnaire used in this study could be rated as high consistency and reliability.

\section{Test of Research Hypotheses}

The purpose of this study was to examine the relationship between five dimensions of service quality of low cost airlines and consumers' post purchase behavioral intentions. The hypothesis in this study was there is a significant relationship between the five dimensions of service quality on customers' post purchase behavioral intention. The result after testing the hypothesis showed that $p$-value was <.05 and $R$ square was equal to 0.314 . This indicated that the five 
dimensions of service quality had a significant relationship on post purchase behavioral intention at 0.314 (31.4\%). In other words, another 68.6 percent might be other factors which were not tested in this study. Details are shown in Table II and Table III.

TABLE I: DEMOGRAPHICS CHARACTERISTICS OF RESPONDENTS

\begin{tabular}{|c|c|c|}
\hline Characteristics & Frequency & $\begin{array}{c}\text { Percentage } \\
(N=425) \\
\end{array}$ \\
\hline \multicolumn{3}{|l|}{ Gender } \\
\hline Male & 251 & 59.1 \\
\hline Female & 174 & 40.9 \\
\hline Total & 425 & 100 \\
\hline \multicolumn{3}{|l|}{ Age } \\
\hline $15-22$ & 40 & 9.4 \\
\hline $23-30$ & 159 & 37.4 \\
\hline $31-45$ & 195 & 45.9 \\
\hline Above 46 & 31 & 7.3 \\
\hline Total & 425 & 100 \\
\hline \multicolumn{3}{|l|}{ Education } \\
\hline Undergraduate & 36 & 8.5 \\
\hline Bachelor degree graduate & 206 & 48.5 \\
\hline Post graduate & 183 & 43.1 \\
\hline Total & 425 & 100 \\
\hline \multicolumn{3}{|l|}{ Net income(Baht) } \\
\hline$<15,000$ Baht & 58 & 13.6 \\
\hline $15,001-25,000 \mathrm{Baht}$ & 121 & 28.5 \\
\hline $25,001-35,000 \mathrm{Baht}$ & 93 & 21.9 \\
\hline $35,001-45,000$ Baht & 44 & 10.4 \\
\hline 45,001-55,000 Baht & 38 & 8.9 \\
\hline$>55,000$ Baht & 71 & 16.7 \\
\hline Total & 425 & 100 \\
\hline \multicolumn{3}{|l|}{ Occupation } \\
\hline Students & 53 & 12.5 \\
\hline Government officers & 59 & 13.9 \\
\hline $\begin{array}{l}\text { Employees of government } \\
\text { Enterprises }\end{array}$ & 17 & 4.0 \\
\hline $\begin{array}{l}\text { Employees of private } \\
\text { companies }\end{array}$ & 213 & 50.1 \\
\hline Business owners & 53 & 12.5 \\
\hline Others & 30 & 7.1 \\
\hline Total & 425 & 100 \\
\hline \multicolumn{3}{|l|}{ Traveling purpose } \\
\hline Business & 43 & 10.1 \\
\hline Visiting friends and family & 46 & 10.8 \\
\hline Travel & 249 & 69.2 \\
\hline Education & 32 & 7.5 \\
\hline Others & 10 & 2.4 \\
\hline Total & 100 & 100 \\
\hline
\end{tabular}

TABLE II: MODEL SUMMARY

\begin{tabular}{ccccc}
\hline \hline Model & $R$ & $R$ Square & $\begin{array}{c}\text { Adjusted } R \\
\text { Square }\end{array}$ & $\begin{array}{c}\text { Std. Error of } \\
\text { Estimate }\end{array}$ \\
\hline 1 & $.560^{\mathrm{a}}$ & .314 & .306 & .82143 \\
\hline \hline
\end{tabular}

a. Predictors: (Constant), total empathy, total tangible, total reliability, total assurance, total responsiveness

b. Dependent Variable: Post purchase behavioral intention

TABLE III: ANOVA RESULTS

\begin{tabular}{llllll}
\hline \hline Model & $\begin{array}{l}\text { Sum of df } \\
\text { Squares }\end{array}$ & $\begin{array}{l}\text { Mean } \\
\text { Square }\end{array}$ & $F$ & Sig. \\
\hline Regression & 129.304 & 5 & 25.861 & 38.327 & $.000^{\mathrm{b}}$ \\
Residual & 282.717 & 419 & .675 & & \\
Total & 412.021 & 424 & & & \\
\hline
\end{tabular}

a. Dependent Variable: Post purchase behavioral intention b. Predictors: (Constant), total empathy, total tangible, total reliability, total assurance, total responsiveness

When analyzing each service quality criteria that participants chose, it found that three service quality dimensions including assurance, reliability, and empathy significantly influenced customers' post purchase behavioral intention. The beta scores in the table below indicated that assurance dimension had the highest beta score at .222 followed by reliability dimension (.213) and empathy dimension (.133). In contrast, it was found in this study that another 2 dimensions-tangible and responsiveness showed no significant influence on customers' post purchase behavioral intention.

\begin{tabular}{llll}
\multicolumn{4}{c}{ TABLE IV: REGRESSION ANALYSIS RESULTS } \\
\hline \hline Model & Beta & t-statistic & Sig. \\
\hline Tangible & .021 & .422 & .673 \\
Reliability & .213 & $3.303^{*}$ & .001 \\
Responsiveness & .062 & .837 & .403 \\
Assurance & .222 & $3.331^{*}$ & .001 \\
Empathy & .133 & $2.109 *$ & .035 \\
\hline \hline$p<.05$ & & &
\end{tabular}

\section{Discussion}

The purpose of this study was to examine the relationship between five dimensions of service quality of low cost airlines and consumers' post purchase behavioral intentions. The results of this study showed that 1)assurance dimension which refers to customers' feeling of security and their trust on prices together with knowledge of airline staff, 2) reliability dimension which refers to punctuality, accuracy and low number of flight cancellations, and 3)empathy dimension which includes tenderness, caring and helpful airline staff who could sincerely display or give to their customers, during their work, had a significant influence on consumers' post purchase behavioral intentions. These findings were also supported by a study conducted by Mayr and Zins [19]. They found in their study that the service quality that could show companies' care to their customers such as good service on board or price guarantee had a positive influence on customers' viewpoints about the airline. Also, Saha and Theingi [3] found a related result presenting that punctuality was the most important factor followed by friendliness of airline staff.

However, some studies presented different findings. For example, Nadiri, Hussain, Ekiz, and Erdogan [20] found that when travelling aboard passengers expected to receive tangible comfort the most. Han [21] found that passengers in a full service airline enjoyed using good quality services and comfortable equipment provided for them on board. If they were happy, they could come back and travel with the same airline again, and they tended to share their onboard service to their friends. Since Han [21] conducted a study with passengers travelling on a full service airline, it is possible that people spending more money expected comfortable service while travelling on board. Passengers travelling with a low cost airline, in contrast, understand about the limitations of comfortable facilities they might get for their inexpensive airfare. However, low cost airline passengers still expect to fly with on-time, safety and reliable flights. For these possible reasons, tangible and responsiveness dimensions did not show a significant influence on post purchase behavioral intentions in this study compared to assurance, reliability and empathy dimensions. 


\section{CONCLUSION}

This study shows that assurance dimensions, reliability dimensions and empathy dimensions display a significant influence on post purchase behavioral intentions. This could suggest that to ensure good quality service that could satisfy the needs of the passengers, low cost airline management teams should ensure that their flights are always on time and reliable; flying according to their schedules; customers are well taken care of; as well as developing an image of an airline concerned with safety, should become their first priority to attract their customers to return and fly with the airline again. Once these first dimensions have been improved, other services could be offered later on. At the same time, the management team must consider potential channels that allow impressed passengers to share their impressions. This can be done through online channels such as social media (Facebook, Twitter), review website, online discussion boards and blogs. Marketing activities as promotions and games that could present good images such as impressions story-telling or pictures could also be undertaken regularly.

This study suggests that further studies should conduct a survey comparing between the attitudes of foreign passengers and Thai passengers regarding their preferred five dimensions of service quality. Also, effective channels and messaging that passengers might use to share their flying experiences with other people should be investigated.

\section{REFERENCES}

[1] IATA. (2012). Airlines to welcome 3.6 billion passengers in 2016. [Online]. Available: http://www.iata.org/pressroom/pr/pages/2012-1206-01.aspx

[2] J. F. O'Connell and G. Williams, "Passengers' perceptions of low cost airlines and full service carriers: A case study involving Ryanair, Aer Lingus, Air Asia and Malaysia Airlines," Journal of Air Transport Management, vol. 11, no. 4, pp. 259-272, 2005.

[3] G. C. Saha et al., "Service quality, satisfaction, and behavioural intentions: A study of low-cost airline carriers in Thailand," Managing Service Quality, vol. 19, no. 3, pp. 350-372, 2009.

[4] J. W. De Jager, D. Van Zyl, and A. L. Toriola, "Airline service quality in South Africa and Italy," Journal of Air Transport Management, vol. 25, pp. 19-21, 2012.

[5] Y. K. Kim and H. R. Lee, "Customer satisfaction using low cost carriers,” Tourism Management, vol. 32, no. 2, pp. 235-243, 2011.

[6] J. W. Park, R. Robertson, and C. L.Wu, "The effect of airline service quality on passengers' behavioural intentions: A Korean case study," Journal of Air Transport Management, vol. 10, no. 6, pp. 435-439, 2004.

[7] K. C. Yang, T. C. Hsieh, H. Li, and C.Yang, "Assessing how service quality, airline image and customer value affect the intentions of passengers regarding low cost carriers," Journal of Air Transport Management, vol. 20, pp. 52-53, 2012.

[8] C. C. Chou, L. J. Liu, S. F. Huang, J. M. Yih and T. C. Han, "An evaluation of airline service quality using the fuzzy weighted SERVQUAL method," Applied Soft Computing, vol. 11, no. 2, pp. 2117-2128, 2011.

[9] D. Gilbert and R. K. C.Wong, "Passenger expectations and airline services: A Hong Kong based study," Tourism Management, vol. 24, no. 5, pp. 519-532, 2003.
[10] D. Holtbrügge, S. Wilson, and N. Berg, "Human resource management at Star Alliance: Pressures for standardization and differentiation," Journal of Air Transport Management, vol. 12, no. 6, pp. 306-312, 2006.

[11] A. Parasuraman, V. Zeithaml, and L. Berry, "SERVQUAL: A multiple-item scale for measuring consumer perceptions of service quality," Journal of Retailin, vol. 64, no. 1, pp. 12-40, 1988.

[12] F. Pakdil and Ö. Aydın, "Expectations and perceptions in airline services: An analysis using weighted SERVQUAL scores," Journal of Air Transport Managemen, vol. 13, no. 4, pp. 229-237, 2007.

[13] L. F. Cunningham, C. E. Young, and M. Lee, "Perceptions of airline service quality: pre and post 9/11," Public Works Management \& Policy, vol. 9, no. 1, pp. 10-25, 2004.

[14] Y. K. Huang, "The effect of airline service quality on passengers' behavioural intentions using SERVQUAL scores a TAIWAN case study," Journal of the Eastern Asia Society for Transportation Studies, vol. 8, pp. 2330-2343, 2010.

[15] J. Hutchinson, F. Lai, and Y. Wang, "Understanding the relationships of quality, value, equity, satisfaction, and behavioral intentions among golf traveler," Tourism Management, vol. 30, no. 2, pp. 298-308, 2009.

[16] B. A. Sparks and V. Browning, "The impact of online reviews on hotel booking intentions and perception of trust," Tourism Management, vol. 32, no. 6, pp. 1310-1323, 2011.

[17] M. Fakharyan, M. R. Jalilvand, M. Elyasi, and M. Mohammadi, "The influence of online word of mouth communications on tourists' attitudes toward Islamic destinations and travel intention: Evidence from Iran," African Journal of Business Management, vol. 6, no. 38 , pp. 10381-10388, 2012.

[18] J. F. Hair, "Multivariate data analysis," 6th ed. Upper Saddle River, NJ: Prentice Hall, 2006.

[19] T. Mayr and A. H. Zins, "Extensions on the conceptualization of customer perceived value: insights from the airline industry," International Journal of Culture, Tourism and Hospitality Research, vol. 6, no. 4, pp. 356-376, 2012.

[20] H. Nadiri, K. Hussain, E. H. Ekiz, and S. Erdogan, "An investigation on the factors influencing passengers' loyalty in the North Cyprus national airline," The TQM Journal, vol. 20, no. 3, pp. 265-280, 2008.

[21] H. Han, "Effects of in-flight ambience and space/function on air travelers' decision to select a low-cost airline," Tourism Management, vol. 37 , pp. 125-135, 2013.

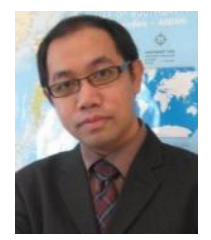

Weerawit Lertthaitrakul is a member of International Economics Development Research Center (IEDRC). He obtained his B.B.A. in Management from Kasetsart University, Thailand and received his M.Sc. in Logistics Management from Chulalongkorn University, Thailand. $\mathrm{He}$ is a Ph.D. candidate in Administration and Management College, King Mongkut's Institute of Technology Ladkrabang, Bangkok, Thailand

Currently, he is a lecturer of Sripatum University, Chonburi Campus. His research interests are in logistics and supply chain management, tourism logistics and marketing management.

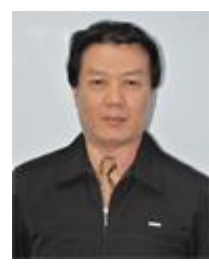

Vinai Panjakajornsak earned his D.B.A. in marketing from University of South Australia. Currently, he is a lecturer of Administration and Management College, King Mongkut's Institute of Technology Ladkrabang, Bangkok, Thailand and he is a director of Ph.D. Program in Industrial Business Administration. His research interests cover Service Marketing, and Logistics 